\title{
Design and Development of Solar Desalination Plant: Point-Focus Parabolic Solar Still
}

\author{
"S.M. Atnaw, R.M. Ramli, S.A. Rusdah, T. Marimuthu, P. Mardarveran, S.S.Yi, M.A. \\ Usop and M.K.M. Gapar
}

Faculty of Engineering Technology, University Malaysia Pahang, Gambang, Pahang

*Email: mekbibsams@ump.edu.my

\begin{abstract}
Direct sunlight has been utilized long back for desalination of water. Solar still is a device that converts saline water to potable water. This project mainly discussed about point-focus parabolic solar still (PPSS). Since lack of water supply has become a serious problem today, this prototype is design to produce fresh water from saline water to enable continuous supply of water. However, the current solar desalination generation capacity is generally low and has high installation cost. Hence, there is a need for the enhancement of the productivity which can be achieved through point focus parabolic solar still. Existing PPSS produces of $3.56 \mathrm{~L} / \mathrm{m}^{2}$ fresh water of per day. In this project, we have some modifications which will increase the productivity of PPSS.
\end{abstract}

Indexed Terms- Solar still; Salinity; Seawater; Desalination.

\section{INTRODUCTION}

\subsection{Background of Study}

About $71 \%$ of the Earth's surface is water-covered and yet it is undeniable that many regions of country still suffer from lack of fresh water supply. The United Nations Environment Programme (UNEP) (1991) acclaimed that one third of the world's population live in countries with insufficient freshwater to support their population .

Apart from that, marine militaries often migrate from one place to another place and they often face difficulties to obtain drinking water. Engineers and technicians working offshore also experienced lack of potable water during summer. Furthermore, villagers staying nearby sea sometimes use seawater for domestic purpose if there is lack of water supplies.

All these prove that continues ability to supply fresh water is essential. Throughout the history, water is extracted only from aquifers and rivers to produce fresh water which is now depleting as well. In order to solve the water crisis, the availability of seawater should be utilized as oceans covered approximately $96 \%$ of the total water in the Earth as shown in Table 1.

An alternative way is found to utilize the seawater which will benefit the humankind and other living things as well. This process is called solar desalination where saline water can be used to convert as freshwater using sunlight. 
Table 1: Estimated global water distribution [2].

\begin{tabular}{ccccc}
\hline Water Source & $\begin{array}{c}\text { Water Volume, in } \\
\text { cubic miles }\end{array}$ & $\begin{array}{c}\text { Water Volume, in } \\
\text { cubic kilometers }\end{array}$ & $\begin{array}{c}\text { Percent of } \\
\text { Fresh } \\
\text { water }\end{array}$ & $\begin{array}{c}\text { Percent of } \\
\text { Total Water }\end{array}$ \\
\hline $\begin{array}{c}\text { Oceans, Seas, \& } \\
\text { Bays }\end{array}$ & $321,000,000$ & $1,338,000,000$ & -- & 96.5 \\
\hline $\begin{array}{c}\text { Ice Caps, Glaciers, } \\
\& \text { Permanent Snow }\end{array}$ & $5,773,000$ & $24,064,000$ & 68.6 & 1.74 \\
\hline Ground Water & $5,614,000$ & $23,400,000$ & -- & 1.7 \\
\hline Fresh & $2,526,000$ & $10,530,000$ & 30.1 & 0.76 \\
\hline Saline & $3,088,000$ & $12,870,000$ & -- & 0.93 \\
\hline Soil Moisture & 3,959 & 16,500 & 0.05 & 0.001 \\
\hline $\begin{array}{c}\text { Ground Ice \& } \\
\text { Permafrost }\end{array}$ & 71,970 & 300,000 & 0.86 & 0.022 \\
\hline Lakes & 42,320 & 176,400 & -- & 0.013 \\
\hline Fresh & 21,830 & 91,000 & 0.26 & 0.007 \\
\hline Saline & 20,490 & 85,400 & -- & 0.007 \\
\hline Atmosphere & 3,095 & 12,900 & 0.04 & 0.001 \\
\hline Swamp Water & 2,752 & 11,470 & 0.03 & 0.0008 \\
\hline Rivers & 509 & 2,120 & 0.006 & 0.0002 \\
\hline Biological Water & 269 & 1,120 & 0.003 & 0.0001 \\
\hline
\end{tabular}

At present, there are many types solar desalination plants located all around the world which is used for small and large scale depend on the purpose. However, few drawbacks were found in the design such as high cost, low efficiency and complexity in designing. In addition, there are losses of heat to the surroundings. Furthermore, yield produced are affected during raining season, and solar dish need to be protected during harsh conditions like rain and high installation cost. So, a prototype known as point focus parabolic solar stills is designed to fulfil the need of people which is to ensure continuous water supply. This project intends to supply fresh water which undergoes solar desalination as well as concerning other factors such as the efficiency, durability and cost. A simple and cost-effective point focus parabolic solar still able to work efficiently and reduce the heat loss at the same time.

\subsection{Objectives}

The objectives of the project are:

1. To investigate the productivity of point-focus parabolic solar still with low cost parabolic dish made up of non-fragile materials.

2. To design low cost solar tracker that compatible for users and efficient as well.

3. To minimize the heat loss in point-focus parabolic solar still and reuse the waste heat through heat exchanger.

\section{LITERATURE REVIEW}

\subsection{Background of Solar Desalination}

Gorjian et al.(2014) defines "desalination" as any process that removes some amount of salt and other minerals from saline water or brackish water and is the well-known treatment solution throughout the world today. Basically, solar desalination can be divided into two which are direct and indirect solar desalination. Direct solar desalination convert solar energy to produce distillate or potable water directly meanwhile indirect solar desalination combines conventional desalination techniques, such as 
multistage flash desalination (MSF), reverse osmosis (RO), membrane distillation (MD) and electrodialysis, with solar collectors for heat generation. Solar stills are the device used to make potable water from the saline water with the aid of solar energy which is considered as direct solar desalination. Solar still can be broadly classified into two categories, active solar still and passive solar still.

\subsection{Comparison of productivity for Different Types of Solar Still}

Table 2: Comparison of Productivity for Solar Stills

\begin{tabular}{lcc}
\hline \multicolumn{1}{c}{ Type of Solar Still } & Capacity $\left(\mathbf{L} / \mathbf{m}^{\mathbf{2}} / \mathbf{d a y}\right)$ & References \\
\hline Basin Type Solar Still & 2.00 & {$[4]$} \\
\hline Wick Still & 4.2 & {$[5]$} \\
\hline Weir type cascade solar still & 3.85 & {$[6]$} \\
\hline Spherical Solar Still & 2.3 & {$[7]$} \\
\hline Double basin still coupled to a collector & 5.181 & {$[8]$} \\
\hline Point-focus parabolic solar still & 3.56 & {$[9]$} \\
\hline
\end{tabular}

\subsection{Limitations of Solar Desalination}

A major concern on desalination facilities that should be considered while increasing productivity is to maintain economic feasibility and simplicity. Rabadia (2015) [10] acclaims that the system components and hardware used to enhance productivity are still expensive often impeding commercialization. Another limitation of desalination is that it may introduce biological or chemical contaminants into water supply. Hence, initiatives should be implement to filter and separate chemical containments such as oil from the saline water. The current project is intended to design and fabricate a stand-alone point-focus parabolic solar still for the desalination of brackish water and purification of non-potable water. The reason for choosing PPSS among others is because PPSS can produce higher yield with lower cost of installation. Compare to the parabolic trough which is use for large scale and require higher cost of installation, PPSS can be used for lower scale and it has a simpler design.

\section{MATERIALS AND METHODOLOGY}

\subsection{Materials}

1. Parabolic dish concentrator

The solar dish concentrator is made of fine-polished aluminum foil and silver colour is coated on dish to increase the reflectivity of the dish.

2. Insulated Absorber

The absorber is made up of double walled glass bottle from vacuum flask. The outer surface is insulated with tempered glass

3. Piping system

For inlet, stainless steel pipe is used as it can reduce the corrosion rate of the pipe due to the flow of salt water and it is economical meanwhile copper pipe is used for outlet.

4. Heat exchanger

The heat exchanger used is copper pipe heat exchanger. There would be thin strips of copper which carries hot fresh water surrounding the inlet pipe that transfer heat to incoming saline water.

5. Single Axis Sun Tracking System

In this design, trackers are incorporated to parabolic dish to keep parabolic solar dish oriented directly towards the sun in one plane-either horizontally or vertically.

6. Stepper motor 
The stepper is integrated in this design to assist the movement of the parabolic solar dish.

7. Light Dependent Resistor (LDR)

LDRs are fixed on the parabolic solar dish in order to make the parabolic dish moves according to the position of sunlight.

8. Water Pump

The water pump would aid in supplying salt water to the insulated absorber through the piping system of the inlet.

\subsection{Methodology}

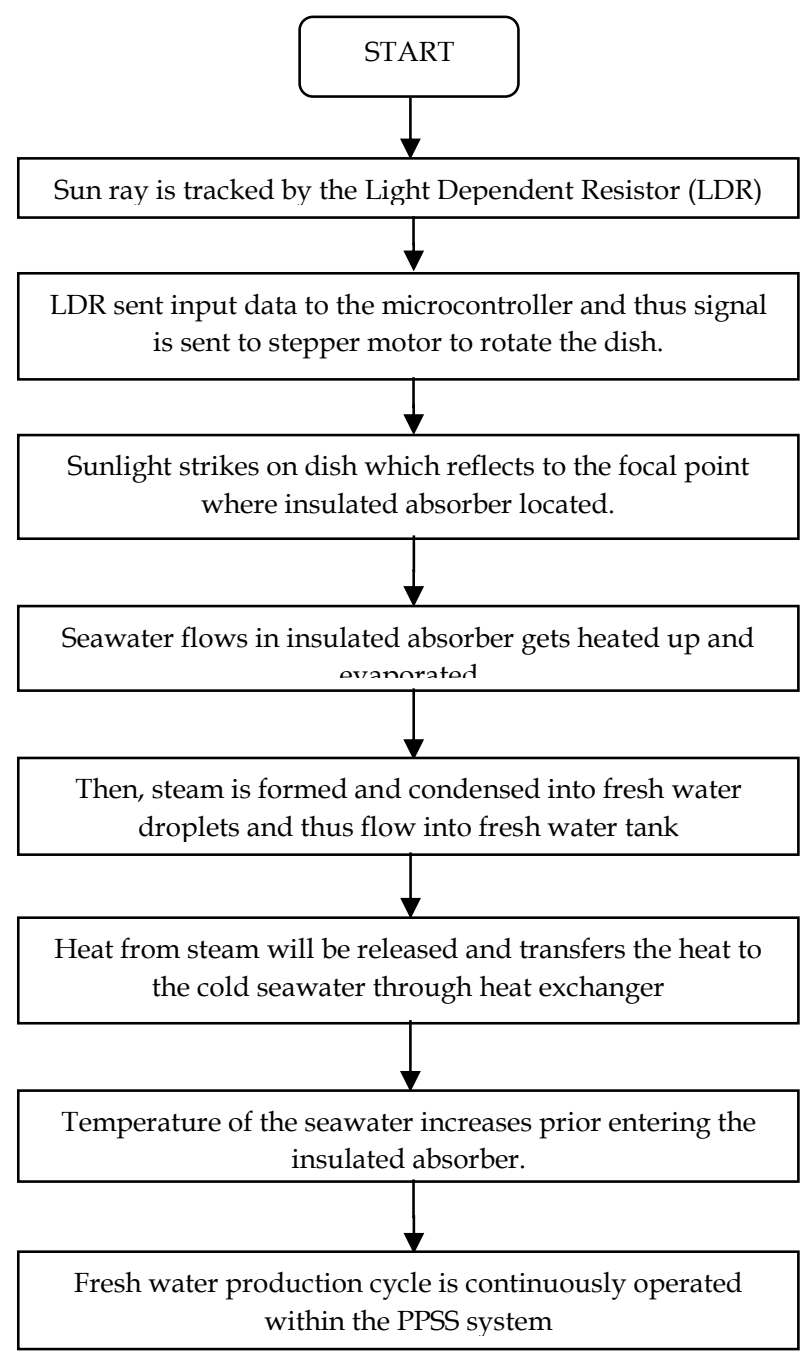

Figure 7: Working principle of stand-alone point-focus parabolic solar stills

\subsection{Analysis}

\subsubsection{Prototype Geometry}

Focal length is use to determine the location of precise and accurate focal point of the insulated absorber where vacuum flask and tempered glass located. The accuracy of the focal point can direct influence the efficiency and productivity of the fresh water.

Calculating the focal length from centre of aperture to the insulated absorber, $f$ 
Table 3: Dimension of the parabolic dish concentrator

\begin{tabular}{cc}
\hline \multicolumn{1}{c}{ Description } & Value \\
\hline Diameter of aperture, $\mathrm{D}_{\mathrm{a}}(\mathrm{m})$ & 0.66 \\
\hline Depth of the parabolic dish, $\mathrm{h}(\mathrm{m})$ & 0.135 \\
\hline Radius of the cylinder, a $(\mathrm{m})$ & 0.06 \\
\hline & \\
$f=\left(D_{2}\right)^{2} / 16 \mathrm{~h}$ & \\
$f=(0.66)^{2} \mathrm{~m}^{2} /[16 \times(0.135 \mathrm{~m})]$ & \\
$f=0.2017 \mathrm{~m}$ &
\end{tabular}

The focal length from centre of aperture to the insulated absorber was $0.2017 \mathrm{~m}$.

3.3.2 Average Temperature in the Absorber of the Parabolic Disc Solar Collector

Table 4: Information and values used to calculate average temperature of absorber

\begin{tabular}{lcc}
\hline \multicolumn{1}{c}{ Description } & Value & Reference \\
\hline Ambient Temperature, $\mathrm{T}_{\text {amb }}$ & $20^{\circ} \mathrm{C}$ or $293.15 \mathrm{~K}$ & {$[11]$} \\
\hline Temperature of the sun, $\mathrm{T}_{\text {sun }}$ & $\begin{array}{c}5526.85^{\circ} \mathrm{C} \quad \text { or } \\
5800 \mathrm{~K}\end{array}$ & {$[12]$} \\
\hline Emissivity of the vacuum flask, $\varepsilon_{\mathrm{r}}$ & 0.09 & {$[13]$} \\
\hline $\begin{array}{l}\text { Maximum efficiency range of the solar } \\
\text { collector }(80 \%-100 \%), \mathrm{n}\end{array}$ & 0.80 & {$[14]$} \\
\hline Maximum concentration ratio, $\mathrm{C}$ & 346.6867 & - \\
\hline Optical efficiency, $n_{\mathrm{o}}$ & 0.9110 & - \\
\hline
\end{tabular}

Calculating average temperature in the insulated absorber of the parabolic disc solar collector, $\mathrm{T}_{\mathrm{rm}}$

Temperature in the absorber of the solar collector could be found through the necessary value given and equation given below [14]:

$T_{r m}=\frac{\operatorname{Tamb}+\operatorname{Tsun} *\left[(1-n) *\left(\frac{n o * C}{46311 * \varepsilon r}\right)\right]}{2}$

$T_{r m}=\frac{20^{\circ} \mathrm{C}+5526.85^{\circ} \mathrm{C} *\left[(1-0.8) *\left(\frac{0.9110 * 346.6867}{46311 * 0.09}\right)\right]}{2}$

$T_{r m}=\frac{103.76^{\circ} \mathrm{C}}{2}$

$T_{r m}=51.88^{\circ} \mathrm{C}$

The average temperature in the insulated absorber of the parabolic dish solar collector was $51.88^{\circ} \mathrm{C}$.

Table 5: Information and values used to calculate thermal efficiency, $\eta_{\text {inst }}$

\begin{tabular}{lcc}
\hline \multicolumn{1}{c}{ Description } & Value & Reference \\
\hline Useful energy delivered in the absorber, $\mathrm{Q}_{\text {out }}(\mathrm{W})$ & 138.4808 & - \\
\hline Area of the aperture, $\mathrm{Aa}\left(\mathrm{m}^{2}\right)$ & 0.3421 & - \\
\hline Mean Direct Radiation from the sun, $\mathrm{I}_{\mathrm{b}}\left(\mathrm{W} / \mathrm{m}^{2}\right)$ & 450 & {$[15]$} \\
& & \\
\hline
\end{tabular}


Calculating the thermal Efficiency, $\eta_{\text {inst }}$ of PPSS system

$\eta_{\text {inst }}=Q_{\text {out }} /\left(\mathrm{A}_{\mathrm{a}} \times \mathrm{I}_{\mathrm{b}}\right)$

$\eta_{\text {inst }}=\frac{138.4808 \mathrm{~W}}{0.3421 \mathrm{~m} 2 \times 450 \frac{\mathrm{W}}{\mathrm{m} 2}}$

$\eta_{\text {inst }}=0.8995 \times 100 \%$

$\eta_{\text {inst }}=89.95 \%$

The thermal efficiency, $\eta_{\text {inst }}$ of PPSS system was $89.95 \%$.

\subsection{Prototype Design}



\section{RESULTS AND DISCUSSIONS}

\subsection{Performance of The Solar Desalination Plant}

The average amount of fresh water produced is $148.3 \mathrm{ml}$ based on three days observation. Table 4.1 shows the volume of fresh water produced for three consecutive days. Based on Table 4.2, the maximum solar irradiance achieved is $1012.9 \mathrm{~W} / \mathrm{m} 2$ at $12.30 \mathrm{pm}$ on Day 2 and the minimum is 187.9 $\mathrm{W} / \mathrm{m} 2$ at $5.30 \mathrm{pm}$ on Day 3.The solar irradiance greatly affects the productivity of the fresh water. Figure 4.1 illustrates the trend of solar irradiance for three days and it clearly shows that the solar irradiance increases till noon and started decreasing towards evening.

Table 4.1: The volume of fresh water produced (ml) for three consecutive days.

\begin{tabular}{ccccc}
$\begin{array}{c}\text { Volume of fresh } \\
\text { water }(\mathbf{m} \boldsymbol{l})\end{array}$ & Day 1 & Day 2 & Day 3 & Average \\
\cline { 2 - 5 } & 120 & 170 & 155 & 148.3 \\
\hline
\end{tabular}


Table 4.2: The solar irradiance $\left(\mathrm{W} / \mathrm{m}^{2}\right)$ for three consecutive days

\begin{tabular}{ccccc}
\hline \multirow{2}{*}{ Time } & \multicolumn{4}{c}{ Solar Irradiance $\left(\mathbf{W} / \mathbf{m}^{2}\right)$} \\
\cline { 2 - 5 } & Day $\mathbf{1}$ & Day $\mathbf{2}$ & Day $\mathbf{3}$ & Average \\
\hline $8.30 \mathrm{am}$ & 575.7 & 470.7 & 315.7 & 454.0 \\
\hline $9.30 \mathrm{am}$ & 821.5 & 891.5 & 413.5 & 708.8 \\
\hline $10.30 \mathrm{am}$ & 845.7 & 940.7 & 448.7 & 745.0 \\
\hline $11.30 \mathrm{am}$ & 895.5 & 975.5 & 690.5 & 853.8 \\
\hline $12.30 \mathrm{am}$ & 910.5 & 1012.9 & 710.5 & 878.0 \\
\hline $1.30 \mathrm{pm}$ & 917.7 & 995.7 & 717.7 & 877.0 \\
\hline $2.30 \mathrm{pm}$ & 895.2 & 870.2 & 595.4 & 786.9 \\
\hline $3.30 \mathrm{pm}$ & 307.2 & 507.2 & 307.2 & 373.9 \\
\hline $4.30 \mathrm{pm}$ & 191.8 & 396.8 & 190.3 & 259.6 \\
\hline $5.30 \mathrm{pm}$ & 192.7 & 295.7 & 187.9 & 225.4 \\
\hline \multicolumn{5}{c}{ Total Average } \\
\hline
\end{tabular}

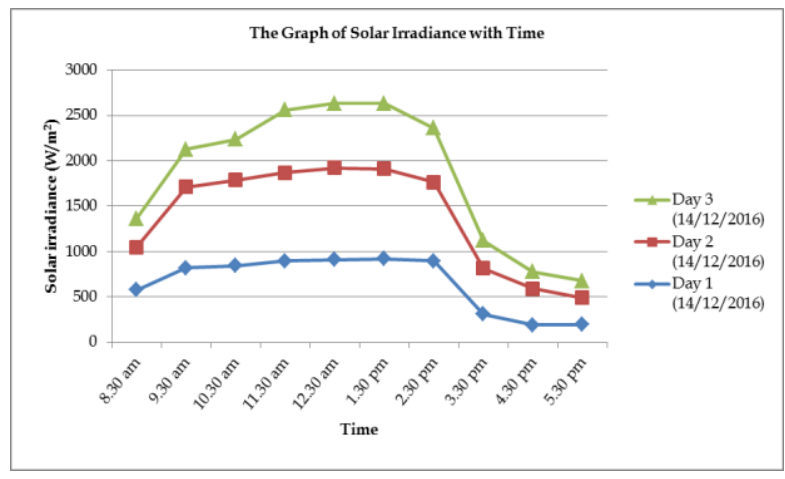

Figure 4.1: The graph of solar irradiance $\left(\mathrm{W} / \mathrm{m}^{2}\right)$ with time for three consecutive days

\subsection{Effect of Salinity and Conductivity}

Based on Table 4.3, the salinity of the fresh water produced from the solar still showed a tremendous reduction. The average salinity obtained is $1.47 \mathrm{ppt}$ and the percentage of reduction is up to $92.78 \%$. By using parabolic focus-point solar still, the conductivity of fresh water obtained is $2.69 \mathrm{mS}$. The percentage reduced is about $93 \%$ for three consecutive days.

Table 4.3: The comparison of average salinity and conductivity of distilled water, seawater and fresh water for three consecutive days.

\begin{tabular}{ccccccccc}
\hline \multirow{2}{*}{$\begin{array}{c}\text { Type of } \\
\text { Water }\end{array}$} & \multicolumn{4}{c}{ Conductivity $(\mathbf{m S})$} & \multicolumn{4}{c}{ Salinity (ppt) } \\
\cline { 2 - 9 } & Day 1 & Day 2 & $\begin{array}{c}\text { Day } \\
\mathbf{3}\end{array}$ & Average & Day 1 & Day 2 & Day 3 & Average \\
\hline Distilled water & 0.04 & 0.04 & 0.04 & 0.04 & 0.04 & 0.04 & 0.04 & 0.04 \\
\hline Seawater & 40.80 & 40.70 & $\begin{array}{c}40.8 \\
0\end{array}$ & 40.77 & 20.40 & 20.30 & 20.10 & 20.37 \\
\hline $\begin{array}{c}\text { Fresh water } \\
\text { (output) }\end{array}$ & 2.85 & 2.54 & 2.67 & 2.69 & 1.42 & 1.45 & 1.53 & 1.47 \\
\hline
\end{tabular}




\subsection{Effectiveness of Heat Exchanger}

The efficiency of the heat exchanger that is used in the parabolic point- focus solar still is up to $37.28 \%$. The rate of heat exchange that takes place between the incoming cold seawater and the outgoing hot fresh water is about $393.42 \mathrm{~J} / \mathrm{h}$. The efficiency of the heat exchanger can be further increased by reducing the heat loss to the surrounding.

\subsection{Economic Analysis}

Annual production of fresh water

It is assumed that the solar irradiance is high throughout the year which is for 340 days

$=148.33 \frac{\mathrm{ml}}{\text { day }} \times \frac{1 \mathrm{~L}}{1000 \mathrm{ml}} \times \frac{340 \text { days }}{1 \text { year }}$

$=50.4322 \mathrm{~L} /$ year

Price of fresh water per litre

1 litre of Reverse Osmosis drinking water

$=\frac{R M 18.00}{11 \text { litre }}$

$=$ RM 1.63 per litre

Annual saving of fresh water

$=$ Annual production of fresh water $(\mathrm{L} / \mathrm{year}) \mathrm{x}$ Price of the fresh water per litre $(\mathrm{RM} / \mathrm{L})$

$=50.4322 \mathrm{~L} /$ year x RM 1.63 per litre

$\approx \mathrm{RM} 82.50$ per year

Capital cost for PPSS $\approx \mathrm{RM} 856.50$

Payback Period of PPSS system

$=\frac{\text { Capital cost for } P P S S \text { system }(R M)}{\text { Annual saving of fresh water }(R M / \text { year })}$

$=\frac{R M 865.50}{R M 82.50 / \text { year }}$

$\approx 11$ years

\section{CONCLUSION}

In a nutshell, fabrication of the simple, cost effective and environmental friendly of Point-Focus Parabolic Solar Still (PPSS) system is enlighten by the critical fresh water shortage issues which faced by the human population and high cost of manufacture, low efficiency and heat loss of the solar desalination plant. In order to increase the effectiveness of the PPSS system, counter-current flow arrangement of the power-pipe heat exchanger and low cost of the sun tracker system were mounted within the PPSS system.

However, low efficiency of the power-pipe heat exchanger was rated as only37.28\% of the heat gained by the power-pipe heat exchanger. Besides that, average productivity of the fresh water with $0.4336 \mathrm{~L} / \mathrm{m}^{2}$ per day was considered lower as compared to the expected outcome of the fresh water which is $4 \mathrm{~L} / \mathrm{m}^{2}$ per day due to some limitations of the PPSS system. Apart from that, $92.78 \%$ and $93.40 \%$ of high percentage of salinity and conductivity removal declared that PPSS system had high efficiency in removing salt contents through the solar desalination process. The present study is a relatively good starting point in fabricating eco-friendly and effective PPSS system to solve shortage of the fresh water supply and further work is needed to further improve the efficiency of the PPSS system. 


\section{RECOMMENDATIONS}

Therefore, some recommendations can be made in order to improve the effectiveness of the PPSS system in various aspects such as reflectivity of the sunlight, productivity of the fresh water, solar radiation absorption and minimize heat loss and wastage. Firstly, Fresnel lenses can be mounted on the surface of the parabolic dish because thin sheet of the Fresnel lenses are designed with multiple refracting planes which improving the concentration incoming light from various angles into a line or single point focus on the insulated absorber. Besides installation of Fresnel lenses, large and parabolic in of parabolic dish mirrors which made up of large surface area and high reflective surface of the optimal-shaped flat metal petals can be fabricated in replacing the parabolic dish concentrator that made up of obsolete Astro dish.

In order to increase the productivity of the fresh water, a small electrically operated wiper should be installed at the upper inner surface of the tempered glass to automatically wipe the water droplets off and collected at the bottom part of the tempered glass. Next, a discharge valve should be mounted at the bottom part of the vacuum flask with the aids of the brine blow down pump to remove excess salt within the vacuum flask. Apart from that, minimize heat loss and increase surface area of the heat exchanger play major roles in increasing the effectiveness and performance of the power-pipe heat exchange. Last but not least, fresh water obtained through the solar desalination process must be tested and analyzed in determining the suitability of the fresh water for drinking purposes.

\section{ACKNOWLEDGEMENT}

We are deeply indebted to goes to our senior design project main supervisor, Dr Samson Mekbib Atnaw for his enormous patient, support and encouragement, guidance, comment, useful recommendation and supervision in designing, development, material purchasing, fabricating, testing performance of the project, thesis writing and mock-presentation along the period of my study in completing Point-Focus Parabolic Solar Still project. We would like to express profound gratitude to our co-supervisors Dr. Roshahliza and Madam Siti Aishah for the invaluable advice from them in guiding us in accomplish this Senior Design Project.

We would like to convey thanks to the teaching engineer from Faculty of Engineering Technology (FTECH) and others who gave the permission in for providing both workshop and laboratory facilities for this research. Our sincere appreciation also extends to all our friends, lecturers, technicians and others who provided assistances and advices. The guidance and support received from all was vital for the success of this research.

\section{REFERENCES}

[1] UNEP. 1991. Freshwater pollution. UNEP/ GEMS Environmental Library. No. 6. Nairobi.

[2] Gleick. 1993. Water in Crisis: A Guide to the World's Fresh Water Resources. Oxford University Press, New York.

[3] Chaouchi, Zrelli and Gabsi. 2007. Desalination of brackish water by means of a parabolic solar concentrator. Desalination. 217(2007) 118-126. DOI: 10.1016/j.desal.2007.02.009

[4] Zaki G., Radhwan A. and Balbeid A. Analysis of assisted coupled solar stills, Solar Energy, 51 (1993) 277-288.

[5] Kassem T.K. 2016. Optimization the Performance of Single Basin Solar Still with Corrugated Wick Surface at High Places. International Research ournal of Engineering and Technology (IRJET). Voume: 03 Issue. e-ISSN: 2395 -0056

[6] Sadeneni, S.B., Halford H. and Boeh C.K. 2008. Theory and experimental investigation of a weir type inclined solar still.Energy 2008;33:71-80.

[7] Arunkumar T. 2012. Productivity enhancements of compound parabolic concentrator tubular solar stills. RenewableEnergyVolume 88, Pages 391-400. 
[8] Tiris. 1998. Experimental study on a solar still coupled with flat plate collector and a single basin solar still. Energy Conversion and Management. pp853-856

[9] Arunkumar T. 2013. The augmentation of distillate yield by using concentrator coupled solar still with phase change material, Desalination 314 (2013) 189-192

[10] Rabadia. 2015. Factors influencing the Productivity of Solar Still. International Journal for Research in Applied Science \& Engineering Technology (IJRASET). Voulme 31 Issue X. ISSn: 2321-9653

[11] Blumberg, Mark S. 2004. Body Heat: Temperature and Life on Earth. New Ed Edition.Cambridge, MA: Harvard University Press.ISBN 0674013697

[12] John, H.S. 2009. The Solar Spectrum. Department Physics \% Astronomy, Oberlin College. PHYS-068. pp1 of 9

[13] Mayank, V. and Varsha, V. 2014. Optimization of Thermal and Economic Performance of a PTSC System through Material Selectivity: A Comparative Study for Efficient Solar Thermal Conversion. International Journal of Engineering Research \& Technology (IJERT). ISSN: 22780181. Vol. 3 Issue 3.

[14] Jorge A., Jairo E. and Andrea L. 2013. Design and construction of a solar collector parabolic dish for rural zones in Colombia. TECCIENCIA, Vol.7 No.14., 14-22.

[15] Aghil, S. Hakemzadeh, M.H. Sopian, K. Sallehuddin, M.H and Sallem, H.Z. 2013. New Formulation for the Estimation of Monthly Average Daily Solar Irradiation for the Tropics: A Case Study of Peninsular Malaysia. International Journal of Photoenergy Volume 2013 (2013), Article ID 174671, 6 pages 